\title{
Enkele kanttekeningen bij het wetsvoorstel bestuur en toezicht rechtspersonen
}

\author{
Prof. mr. S.M. Bartman, mr. C. de Groot, mr. J. Nijlanden \\ prof. mr. drs. I.S. Wuisman $n^{*}$
}

\begin{abstract}
Met het wetsvoorstel voor de Wet bestuur en toezicht rechtspersonen wordt beoogd de kwaliteit van bestuur en toezicht bij verenigingen, coöperaties, onderlinge waarborgmaatschappijen en stichtingen te verbeteren. In dit artikel bespreken de auteurs kort enkele aspecten van het wetsvoorstel in het licht van de doelstelling en de bruikbaarheid in de praktijk.
\end{abstract}

\section{Inleiding}

Op 8 juni 2016 heeft de regering het wetsvoorstel voor de 'Wet bestuur en toezicht rechtspersonen' aangeboden aan de Tweede Kamer (hierna: WBTR of wetsvoorstel). ${ }^{1}$ Met het wetsvoorstel wordt beoogd de kwaliteit van bestuur en toezicht bij verenigingen, coöperaties, onderlinge waarborgmaatschappijen en stichtingen te verbeteren. Deze doelstelling zou door aanvulling en verduidelijking van de regeling voor bestuur en toezicht bij de verschillende soorten rechtspersonen moeten worden gerealiseerd. In de toelichting bij het wetsvoorstel is opgenomen dat door de voorgestelde wijzigingen in een behoefte van de praktijk wordt voorzien. ${ }^{2}$ In dit artikel bespreken wij kort enkele aspecten van het wetsvoorstel in het licht van de doelstelling en de bruikbaarheid in de praktijk. Paragraaf 2 bespreekt het wetsvoorstel op hoofdlijnen. In paragraaf 3 wordt de bruikbaarheid van de doelstelling van het wetsvoorstel besproken. In de paragrafen 4 en 5 worden respectievelijk de voorstellen met betrekking tot het toezicht op rechtspersonen en de aansprakelijkheid van de bestuurders en commissarissen van verenigingen en stichtingen besproken. Besluitvorming door één of meer taakbelaste bestuurders staat

\footnotetext{
Prof. mr. S.M. Bartman is hoogleraar Ondernemingsrecht aan de Universiteit Leiden. Mr. C. de Groot is universitair hoofddocent aan de Universiteit Leiden. Mr. J. Nijland is universitair docent Ondernemingsrecht aan de Universiteit Leiden. Prof. mr. drs. I.S. Wuisman is hoogleraar Ondernemingsrecht aan de Universiteit Leiden.

1. Handelingen II 2015/16, 34491, Wijziging van het Burgerlijk Wetboek in verband met de uniformering en de verduidelijking van enkele bepalingen omtrent het bestuur en de raad van commissarissen van rechtspersonen (Wet bestuur en toezicht rechtspersonen), nr. 1, Koninklijke Boodschap, nr. 2 herdruk, voorstel van wet en nr. 3, memorie van toelichting (8 juni 2016).
}

2. Kamerstukken II $2015 / 16,34491,3$, p. 1. centraal in paragraaf 6 , waarna in paragraaf 7 een conclusie volgt.

\section{Het wetsvoorstel in het kort}

Het belangrijkste onderdeel van het wetsvoorstel betreft de aanpassing van titel 1 van Boek 2 van het Burgerlijk Wetboek (BW). ${ }^{3}$ Daartoe worden enkele bepalingen opgenomen over het bestuur en toezicht bij rechtspersonen die voor alle in Boek 2 BW geregelde rechtspersonen zullen gelden. Het voorgestelde Ontwerp-artikel 2:9 BW omschrijft de bestuurstaak en Ontwerp-artikel 2:9a BW maakt het voor alle rechtspersonen mogelijk te kiezen voor een monistisch bestuursmodel waarin het bestuur bestaat uit uitvoerende bestuurders en niet-uitvoerende bestuurders. Ontwerp-artikelen 2:9b en 2:9c BW gaan respectievelijk over de interne bestuurdersaansprakelijkheid en de bestuurdersaansprakelijkheid in faillissement. Ontwerp-artikel 2:11 BW makt het voor alle rechtspersonen mogelijk te kiezen voor een dualistisch bestuursmodel met een bestuur en een raad van commissarissen (hierna: $\mathrm{RvC}$ ). Ontwerp-artikel 2:11a BW regelt de informatieverschaffing door het bestuur aan de RvC. De daaropvolgende Ontwerp-artikelen $2: 11 \mathrm{~b}$ en $2: 11 \mathrm{c}$ BW regelen respectievelijk de interne aansprakelijkheid van commissarissen en de aansprakelijkheid van commissarissen in faillissement. Ontwerp-artikel 2:11c BW doet dat door eenvoudigweg te bepalen: 'Het in artikel 9c bepaalde is van overeenkomstige toepassing op commissarissen (...).' Het wetsvoorstel laat artikel 2:10 BW over de administratieplicht van het bestuur ongewijzigd.

Het opnemen van de voorgestelde bepalingen over bestuur en toezicht bij rechtspersonen in titel 1 van Boek 2 BW heeft als gevolg dat de huidige bepalingen in Boek $2 \mathrm{BW}$ over bestuur en toezicht worden aangepast of vervallen. Aangepast worden onder meer de artikelen 2:44 (bestuurstaak bij de vereniging: lid 1 vervalt), 2:129/239 (bestuurstaak bij de naamloze ven-

3. Zie uitgebreid over het voorstel B.A. de Ruijter, Storm op komst voor bestuurders en commissarissen in de semipublieke sector. De Wet bestuur en toezicht rechtspersonen komt eraan!, MvO 2016, afl. 8 \& 9, p. 187-193 en P.J. Dortmond, Het Wetsontwerp bestuur en toezicht rechtspersonen en het verenigingsrecht, Ondernemingsrecht 2016/82. 


\section{Maandblad \\ Ondernemingsrecht}

nootschap (hierna: NV) en de besloten vennootschap (hierna: BV): de leden 1, 2, 5 en 6 vervallen) en 2:291 (bestuurstaak bij de stichting: lid 1 vervalt) BW. Wat geheel vervalt zijn onder meer de artikelen 2:57 en 2:57a (RvC bij de coöperatie en de onderlinge waarborgmaatschappij), 2:129a/239a (monistisch bestuursmodel bij de NV en de BV), 2:138/248 (bestuurdersaansprakelijkheid in faillissement bij de $\mathrm{NV}$ en de BV), 2:140/250 ( $\mathrm{RvC}$ bij de NV en de BV) en ten slotte 2:141/251 (informatieverschaffing door het bestuur aan de $\mathrm{RvC}$ bij de NV en de BV) BW.

\section{Achtergrond van het wetsvoorstel}

Bevat het wetsvoorstel derhalve voornamelijk een stroomlijning van titel 1 van Boek 2 BW ter zake bestuur en toezicht bij alle rechtspersonen, het is nochtans duidelijk een reactie van de wetgever op de affaires die zich de afgelopen jaren bij vooral stichtingen en corporaties in de semipublieke sector hebben voorgedaan, met veel verlies aan gemeenschapsgeld tot gevolg. Denk onder meer aan de spraakmakende calamiteiten bij woningcorporaties (Rochdale, Vestia), de gezondheidszorg (Philadelphia, Meavita) en in het onderwijs (Amarantis, ROC Leiden). De memorie van toelichting (hierna: MvT) geeft ook aan dat het wetsvoorstel beoogt invulling te geven aan de aanbevelingen van de Commissie Maatschappelijk verantwoord bestuur en toezicht in de semipublieke sector, onder voorzitterschap van oud-Tweede Kamerfractievoorzitter van GroenLinks mevrouw Halsema. ${ }^{4}$ Verbetering van de kwaliteit van bestuur en toezicht in juist die semipublieke sector zou dus voorop moeten staan bij dit wetsvoorstel.

Tegen die achtergrond is het dan teleurstellend te moeten constateren dat het wetsvoorstel veeleer dreigt uit te monden in een juridisch-technische exercitie gericht op aanvulling en verduidelijking van het rechtspersonenrecht in het algemeen, dan in een gerichte actie om zonnekoninggedrag en een gebrek aan 'rolvastheid' ('De bestuurders besturen, de interne toezichthouders houden dat in het oog'5) te bestrijden bij stichtingen en verenigingen waarin veel gemeenschapsgeld omgaat. Typerend hiervoor is de passage in de MvT die luidt: 'Het Nederlandse ondernemingsrecht wordt zo merkbaar beter hanteerbaar en daarmee ook aantrekkelijker.' Ofschoon er uiteraard niets mis is met het streven om het Nederlandse ondernemingsrecht aantrekkelijker te maken (voor wie overigens?), betwijfelen wij of het daar nu oorspronkelijk om te doen was.

\section{Toezicht}

Zoals gezegd, beoogt het wetsvoorstel de kwaliteit van bestuur en toezicht bij rechtspersonen te verbeteren door onder meer het stichtings- en verenigingsrecht op enkele punten aan te vullen en te verduidelijken. Een van die onderdelen betreft het creëren van een expliciet in de wet opgenomen grondslag tot het instellen van een statutair toezichthoudend orgaan bij

4. Kamerstukken II 2015/16, 34491, 3, p. 3.

5. Zie Ontspoorde ambitie. Rapport van de Commissie onderzoek huisvesting ROC Leiden, Den Haag, 1 december 2015, p. 93. stichtingen en verenigingen. Een dergelijke grondslag ontbreekt tot nu toe in Boek $2 \mathrm{BW}$ en is slechts in enkele sectorale regelgeving te vinden. ${ }^{6}$ Overigens vormt het ontbreken van zo'n grondslag in Boek 2 BW voor de praktijk geen enkel beletsel om bij stichtingen en verenigingen toch een raad van toezicht in de statuten op te nemen. Het ontbreken van een wettelijke grondslag daartoe wordt kennelijk niet ervaren als een schrijnend gemis. Datzelfde geldt voor het tot nu toe ontbreken van een wettelijke grondslag voor de invoering van een monistisch bestuurssysteem bij stichtingen en verenigingen. Voor alle duidelijkheid, het wetsvoorstel schrijft niet voor dat stichtingen en verenigingen van een bepaalde omvang of signatuur verplicht zijn om een $\mathrm{RvC}$ in te stellen, laat staan dat dit voor alle stichtingen of verenigingen wordt voorgeschreven. Dit laatste zou in algemene zin ook niet wenselijk zijn omdat dan ook verenigingen en stichtingen met een kleine omvang daartoe verplicht zouden worden (met alle kosten van dien). Maar afgezet tegen de geschetste, werkelijke achtergrond van dit initiatief van de wetgever zou er ons inziens wel iets voor te zeggen zijn om een dwingende checks and balances voor te schrijven bij rechtspersonen die in overwegende mate worden gefinancierd met publieke middelen en/of die zich de vervulling van een (semi)publieke taak ten doel stellen. Hopelijk is er nog tijd en ruimte om het debat hierover in het parlement te voeren. Overigens is in de vaste commissie voor Veiligheid en Justitie van de Tweede Kamer door de leden van de D66-fractie de vraag gesteld waarom de regering een vorm van toezicht binnen stichtingen niet verplicht wil stellen. ${ }^{7}$

Wordt eenmaal een $\mathrm{RvC}$ - onder welke benaming dan ook ${ }^{8}$ bij een stichting of vereniging ingesteld, dan geldt na invoering van het wetsvoorstel dat zijn leden alsdan ook vallen onder het - vanwege wettelijke bewijsvermoedens en een gefixeerde schadeomvang nogal draconische - aansprakelijkheidsregime van de antimisbruikwetgeving, zoals dat reeds in 1986 voor NV's en BV's is ingevoerd (art. 2:138/248 BW). Een uitzondering is slechts voorzien voor onbezoldigde (bestuurders en) commissarissen van niet-commerciële stichtingen en verenigingen en van informele verenigingen (Ontwerp-art. 2:11c jo. Ontwerp-art. 2:9c BW). Zie hierover nader paragraaf 5.

Op grond van het wetsvoorstel vallen commissarissen bij stichtingen en verenigingen ook onder de met de huidige NV/BVregeling gestroomlijnde regeling inzake tegenstrijdig belang (art. 2:140/250 lid 5 BW). Het wetsvoorstel brengt ook deze regeling onder in de algemene titel van Boek 2 BW (Ontwerpart. 2:11 lid $6 \mathrm{BW}$ ). De huidige regeling voor de NV en de BV bevat een primaire en een subsidiaire bevoegdheidsallocatie

6. Zie voor een overzicht van sectorale wetgeving waarin wel een toezichthoudend orgaan wordt voorgeschreven, de bijlage bij het advies Raad van State en nader rapport, Kamerstukken II 2015/16, 34491, 4.

7. Handelingen II 2015/16, 34491, Wijziging van het Burgerlijk Wetboek in verband met de uniformering en de verduidelijking van enkele bepalingen omtrent het bestuur en de raad van commissarissen van rechtspersonen (Wet bestuur en toezicht rechtspersonen), nr. 5, verslag ( 9 september 2016), p. 4.

8. Vgl. Kamerstukken II 2015/16, 34491, 3, p. 4 en 20. 
aan respectievelijk de $\mathrm{RvC}$ en de algemene vergadering bij aanwezigheid van een tegenstrijdig belang van een bestuurder. Probleem is echter dat de stichting geen leden kent en bovendien geen $\mathrm{RvC}$ hoeft te hebben, ook niet, zoals we hebben gezien, onder de vigeur van het wetsvoorstel. Tja, welk orgaan blijft dan over om beslissingsbevoegd te maken bij constatering van een tegenstrijdig belang binnen het bestuur? Slechts het bestuur zelf. Dat is uiteraard op voorhand geen bijster effectieve regeling. Om dit zwakke punt - dat nu eenmaal inherent is aan de corporate governance-structuur van de stichting - nog enigszins te versterken, schrijft Ontwerp-artikel 2:11 lid $6 \mathrm{BW}$ voor dat de $\mathrm{RvC}$ van de betreffende stichting het besluit neemt 'onder schriftelijke vastlegging van de overwegingen die aan het besluit ten grondslag liggen, tenzij de statuten anders bepalen'. Volgens de MvT wordt hiermee bedoeld dat bij ontbreken van een $\mathrm{RvC}$ het bestuur alsnog bevoegd is, maar dat dan wel de overwegingen achter het besluit schriftelijk moeten worden vastgelegd. ${ }^{9}$ Op de keper beschouwd zegt de huidige tekst van lid 6 echter niets over de situatie waarin een $\mathrm{RvC}$ ontbreekt. Hier moet in elk geval tekstueel nog wat worden gesleuteld.

$\mathrm{Al}$ met al maakt het wetsvoorstel het weinig aantrekkelijk om toe te treden tot de $\mathrm{RvC}$ van een (commerciële) stichting of vereniging na invoering van het wetsvoorstel. Ook voor de rechtspersoon zelf wordt de - nogmaals vrije - keuze voor een $\mathrm{RvC}$ niet buitengewoon bevorderd. Aantrekkelijker is het wellicht om op gezette tijden en bij saillante besluiten maar het advies van een extern adviesbureau in te winnen.

\section{Aansprakelijkheid van bestuurders en commissarissen van verenigingen en stichtingen}

Het huidige artikel 2:9 BW regelt de interne bestuurdersaansprakelijkheid. Op grond van deze bepaling is iedere bestuurder 'voor het geheel aansprakelijk terzake van onbehoorlijk bestuur, tenzij hem mede gelet op de aan anderen toebedeelde taken geen ernstig verwijt kan worden gemakt en hij niet nalatig is geweest in het treffen van maatregelen om de gevolgen van onbehoorlijk bestuur af te wenden'. Het huidige artikel 2:138/248 BW regelt de externe bestuurdersaansprakelijkheid in faillissement. Op grond van deze bepaling is iedere bestuurder van een $\mathrm{NV}$ en een $\mathrm{BV}$ in geval van faillissement tegenover de boedel 'hoofdelijk aansprakelijk' voor het faillissementstekort, 'indien het bestuur zijn taak kennelijk onbehoorlijk heeft vervuld en aannemelijk is dat dit een belangrijke oorzaak is van het faillissement'. Voor NV's en BV's is zowel artikel 2:9 BW als artikel 2:138/248 BW van overeenkomstige toepassing op de $\mathrm{RvC}$. Dat is neergelegd in artikel 2:149/259 BW.

Wat betreft verenigingen en stichtingen is artikel 2:9 BW rechtstreeks toepasselijk op de bestuurders. Maar de toepasselijkheid van de externe bestuurdersaansprakelijkheid in faillissement wordt thans nog geregeld via een schakelbepaling.

9. Zie Kamerstukken II 2015/16, 34491, 3, p. 6.
Artikel 2:50a/300a BW bepaalt dat artikel 2:138 BW wel van overeenkomstige toepassing is op verenigingsbestuurders en stichtingsbestuurders, maar alleen indien het gaat om een 'formele' vereniging (waarvan de statuten zijn opgenomen in een notariële akte), en alleen indien de vereniging of stichting onderworpen is aan de heffing van vennootschapsbelasting. De toepassing van zowel artikel 2:9 BW als artikel 2:138 BW op leden van het toezichthoudend orgaan van een vereniging of stichting is zelfs afhankelijk van twee schakelbepalingen. De eerste is artikel 2:50a/300a BW, dat artikel 2:149 BW van overeenkomstige toepassing verklaart. De tweede is artikel 2:149 BW, dat de artikelen 2:9 en 2:138 BW van overeenkomstige toepassing verklaart op leden van de $\mathrm{RvC}$ van een vereniging en een stichting. Maar ook hier weer alleen indien het gaat om een formele vereniging, en alleen indien de vereniging of stichting onderworpen is aan de heffing van de vennootschapsbelasting.

In het wetsvoorstel wordt het huidige artikel 2:9 BW voor bestuurders overgezet naar Ontwerp-artikel 2:9b BW en voor commissarissen naar Ontwerp-artikel 2:11b BW. Het huidige artikel 2:138/248 BW transfereert voor bestuurders naar Ontwerp-artikel 2:9c BW en voor commissarissen naar Ontwerp-artikel 2:11c BW. De WBTR-bepalingen zijn algemeen geformuleerd en maken in eerste instantie geen onderscheid tussen enerzijds NV's en BV's en anderzijds verenigingen en stichtingen. Dat betekent dus voor verenigingen en stichtingen een verbreding van het toepassingsbereik van zowel de interne aansprakelijkheid als de externe aansprakelijkheid in faillissement, omdat de hiervoor genoemde beperkingen worden opgeheven. Hierop geldt evenwel, in tweede instantie, één uitzondering. Die uitzondering betreft het huidige artikel 2:138 lid 2/248 lid 2 BW. Dat artikel bepaalt dat indien het bestuur (en bij overeenkomstige toepassing: de $\mathrm{RvC}$ ) niet heeft voldaan aan de administratieplicht van artikel 2:10 BW of de plicht tot tijdige openbaarmaking van de jaarrekening op grond van artikel 2:394 BW, de curator een belangrijk bewijsvoordeel krijgt. Dan staat immers (zonder mogelijkheid van tegenbewijs) vast dat over de volle breedte sprake is van onbehoorlijk bestuur of van onbehoorlijke vervulling van het commissariaat, en wordt (met mogelijkheid van tegenbewijs) vermoed dat die onbehoorlijke takkvervulling een belangrijke oorzaak is van het faillissement. De voorgestelde regelingen van de faillissementsaansprakelijkheid voor bestuurders in Ontwerp-artikel 2:9c BW en voor commissarissen in Ontwerp-artikel 2:11c BW (dat eenvoudigweg verwijst naar Ontwerp-art. 2:9c BW) bepalen dat dit voor de curator zo gunstige bewijsvoordeel niet werkt als het gaat om (1) 'een onbezoldigd bestuurder' (en een onbezoldigd commissaris) van een informele vereniging en (2) 'een onbezoldigd bestuurder' (en een onbezoldigd commissaris) 'van een vereniging of stichting die niet aan de heffing van de vennootschapsbelasting is onderworpen'. Hier wordt de inhoud van de huidige schakelbepaling artikel 2:50a/300a BW dus in iets aangepaste bewoordingen overgenomen, met dien verstande dat het bewijsvoordeel slechts wegvalt als het om 'een onbezoldigd 


\section{Maandblad \\ Ondernemingsrecht}

bestuurder' (en een onbezoldigd commissaris) gaat. Dat komt erop neer dat bezoldigde bestuurders (en commissarissen) van informele verenigingen, alsook bezoldigde bestuurders (en commissarissen) van zowel informele als formele verenigingen en stichtingen die aan de heffing van de vennootschapsbelasting zijn onderworpen, onder het bereik van het huidige artikel 2:138/248 BW worden gebracht. Voor bestuurders en commissarissen van commerciële verenigingen en stichtingen die aan de heffing van de vennootschapsbelasting zijn onderworpen, verandert het aansprakelijkheidsregime dus niet: zij vielen al onder het bereik van het huidige artikel 2:138/248 $\mathrm{BW}$, en vallen straks onder het regime van het voorgestelde artikel 2:9c en 2:11c BW. Maar bij niet-commerciële verenigingen en stichtingen - die niet aan de heffing van de vennootschapsbelasting zijn onderworpen - kan de voorgestelde regeling een uitnodiging zijn om de status van bezoldigd bestuurder of commissaris te verwisselen voor een status van onbezoldigd bestuurder of commissaris, maar dan wel met een ruimhartige onkostenvergoeding in plaats van een vaste remuneratie. Ontwijking van de antimisbruikwetgeving is wel een extra onderhandelingsronde waard. Dit is tegelijkertijd een argument om de onbezoldigheidsexceptie uit het wetsvoorstel te schrappen. Daarvoor pleit ook dat het argument van onbezoldigdheid, dat ook onder de huidige wettelijke regeling wel wordt aangevoerd, in de rechtspraak weinig weerklank vindt. ${ }^{10}$

Dit alles leidt ten opzichte van de huidige situatie tot een aanzienlijke verbreding van het aansprakelijkheidsregime. In de eerste plaats wordt de interne aansprakelijkheidsregeling voor bestuurders en commissarissen van toepassing op alle commissarissen van verenigingen en stichtingen. En in de tweede plaats wordt de faillissementsaansprakelijkheid in beginsel van toepassing op alle bestuurders en commissarissen van verenigingen en stichtingen, met alleen als uitzondering dat het bewijsvoordeel dat de curator kan ontlenen aan het huidige artikel 2:138 lid 2/248 lid 2 BW voor sommige bestuurders en commissarissen niet van toepassing is.

Hier past wel een woord van relativering. Wie de actualiteit enigszins gevolgd heeft, weet dat een faillissement in de semipublieke sector lang niet altijd het sluitstuk is van wanbeheer en gebrek aan effectief toezicht. Juist omdat het de continuïteit van een semipublieke taak betreft (onderwijs, zorg, huisvesting, pensioenvoorziening), treedt de overheid of, zoals bij Rochdale, de sector zelf op als last resource-financier van de instelling in last. De mogelijkheid van een faillissement van het ROC Leiden is in de Tweede Kamer nadrukkelijk besproken, maar uiteindelijk, evenals door de regering, verworpen. ${ }^{11}$ Volgt er geen faillissement, dan komt er ook geen curator die bijvoorbeeld de antimisbruikwetgeving kan inzetten om bestuurders en commissarissen persoonlijk aan te spreken. Aldus beschouwd is het instrument van de interne aansprakelijkheid (art. 2:9 BW) voor de stichting en vereniging in de

10. Vgl. (in het kader van art. 2:9 BW): Hof Amsterdam 12 juni 2012, JOR 2012/348 (Het Nederlandse Rode Kruis/X).

11. Kamerstukken II 2014/15, 34495, 71. semipublieke sector praktisch gesproken veel belangrijker dan dat van de externe aansprakelijkheid ingevolge de huidige artikelen 2:300a en 2:50a BW en het Ontwerp-artikel 2:9c BW uit het wetsvoorstel.

Probleem is nu echter dat een dechargebesluit een effectieve barrière kan opwerpen - en dat in de praktijk ook dikwijls doet - tegen een claim van de rechtspersoon op grond van artikel 2:9 BW. ${ }^{12}$ Gevolg is dat de rechtspersoon die zijn (oud-)bestuurders wil aanspreken, gedwongen is om eerst het dechargebesluit vernietigd te krijgen, waarbij de vordering moet worden ingesteld binnen de vervaltermijn van artikel 2:15 lid $5 \mathrm{BW}$. Vaak is het daarvoor al te laat. Een alternatief is het, eventueel na ommekomst van die vervaltermijn, starten van een enquêteprocedure (art. 2:346 lid 1 sub d BW) met het oog op de vernietiging van het dechargebesluit als eindvoorziening (art. 2:356 sub a BW). Dit is echter een moeizame en kostbare procedure, die ook wat oneigenlijk aandoet. En hoewel de uitkomst ervan onzeker is, staat meer ongewenste publiciteit voor de instelling vast. Dat motiveert niet echt om (ex-)bestuurders namens de rechtspersoon aan te spreken. Dit alles levert niet alleen voor de betreffende rechtspersoon en zijn opvolgende bestuurders, maar ook voor de financierende overheid dikwijls een onbevredigend, ja zelfs frustrerend beeld op. Vaak zijn er al de nodige onderzoeken geweest en staat het falen van bestuurders bij de instelling feitelijk vast. Een gang naar de Ondernemingskamer is dan slechts meer van hetzelfde en wordt terecht als overbodig beschouwd. Kortom, het dechargebesluit van de rechtspersoon, soms genomen door toezichthouders wier eigen optreden (ook) bepaald niet vlekkeloos is geweest, vormt in de praktijk dikwijls een effectieve barrière voor het persoonlijk aanspreken van de bestuurders dan wel van hun voorgangers voor de schade die zij de instelling hebben toegebracht.

Wij vinden het zacht gezegd opmerkelijk dat het wetsvoorstel met geen woord van deze kernproblematiek rept. Het illustreert het feit dat het wetsvoorstel dreigt te verworden tot een juridisch-technische opknapbeurt van Boek 2 BW in plaats van een gerichte actie om - rekening houdend met de specifieke corporate governance-structuur van vooral de stichting - lessen te trekken uit het recente verleden. En dat terwijl de oplossing zo eenvoudig is! Een van de auteurs (prof. mr. S.M. Bartman) heeft bij gelegenheid van het Ondernemingsrechtdiner 2014 in zijn voordracht al voorgesteld om het wetsvoorstel aan te vullen met de volgende bepaling:

'Een besluit van de rechtspersoon dat strekt tot ontslag van aansprakelijkheid van bestuurders of commissarissen tegenover de rechtspersoon wegens het door hen gevoerde beleid, respectievelijk het door hen verrichte toezicht,

12. Bij stichtingen die een raad van toezicht hebben, bepalen de statuten vaak dat de raad van toezicht de bestuurders benoemt en dat de leden van de raad van toezicht worden benoemd door de raad van toezicht zelf. De raad van toezicht is dan bevoegd de bestuurders te dechargeren, terwijl de leden van de raad van toezicht niet worden gedechargeerd. 
heeft geen rechtsgevolg indien en zolang het overheidsorgaan dat de rechtspersoon in belangrijke mate financiert daarmee niet schriftelijk heeft ingestemd.'

Dit voorstel zou (wellicht met een uitbreiding naar 'het overheidsorgaan dat verantwoordelijk is voor de toelating', die vereist is voor woningcorporaties op grond van de Woningwet en voor zorgaanbieders op grond van de Wet toelating zorginstellingen) de dechargeproblematiek in belangrijke mate opzijschuiven. Mits uiteraard het verantwoordelijke overheidsorgaan zijn beslissing om in te stemmen met het dechargebesluit neemt op basis van voldoende adequate informatie en op basis van eigen gedegen onderzoek.

\section{Besluitvorming door één of meer taakbelaste bestuurders}

Het wetsvoorstel voorziet - in tegenstelling tot het Ambtelijk voorontwerp Voorstel van Wet bestuur en toezicht rechtspersonen - in de introductie van het facultatieve monistische bestuursmodel voor de vereniging, de onderlinge waarborgmaatschappij, de coöperatie en de stichting. De behoefte daaraan zou zijn gebleken uit de consultatie die in verband met het Voorontwerp heeft plaatsgevonden. ${ }^{13}$ De consultatiereacties verwijzen naast de ervaringen in het kader van verrichte juridische advisering onder andere naar sectorale wet- en regelgeving die een dergelijk bestuursmodel al mogelijk maken, zoals de Wet versterking bestuur pensioenfondsen, ${ }^{14}$ de Gedragscode goed bestuur en integriteit publieke omroep ${ }^{15}$ en de Wet educatie en beroepsonderwijs. ${ }^{16}$

De regeling voor het monistische bestuursmodel is opgenomen in Ontwerp-artikel 2:9a BW. In dit artikel komen verschillende bepalingen samen die nu verspreid staan in diverse artikelen van Boek $2 \mathrm{BW}$ en die van toepassing zijn op de BV en de NV. ${ }^{17}$ In Ontwerp-artikel 2:9a BW is daarom tevens het equivalent van artikel 2:129a/239a lid 3 BW opgenomen. Het voorgestelde Ontwerp-artikel 2:9a lid 2 BW bepaalt derhalve

13. Kamerstukken II 2015/16, 34491, 3, p. 9. Zie o.a. de volgende reacties die zijn te raadplegen via <www.internetconsultatie.nl/ bestuurentoezichtrechtspersonen/reacties>: CMS Derks Star Busmann NV, p. 2, Ellen Timmer, p. 1, Gecombineerde Commissie Vennootschapsrecht, p. 5-6, Houthoff Buruma, p. 2-3, Loyens \& Loeff NV, p. 10 NautaDutilh, p. 2, Rutgers \& Posch, artikel in het FD van 3 maart 2014, Simmons \& Simmons LLP, p. 9 en ZIFO, p. 1-2. Mede naar aanleiding van de consultatiereacties is de regeling voor het monistische bestuurssysteem in het WBTR opgenomen. In het kader van het Ambtelijk voorontwerp Voorstel van Wet bestuur en toezicht rechtspersonen en het wetsvoorstel bestuur en toezicht vermeldde de minister dat nog niet bleek dat er in de praktijk behoefte was aan een one-tier board voor de andere rechtspersonen: Kamerstukken II 2008/09, 31763, 6, p. 17.

14. Wet van 10 juli 2013 tot wijziging van de Pensioenwet en enige andere wetten in verband met versterking van het bestuur bij pensioenfondsen en enige andere wijzigingen (Wet versterking bestuur pensioenfondsen), Stb. 2013, 302: art. 101a.

15. Zie <www.npointegriteit.nl/wp-content/uploads/2012/02/Gedragscode_ goed_bestuur_en_integriteit_Publieke_Omroep_2012.pdf $>:$ 1.4.2.

16. Wet van 12 maart 2009 tot wijziging van de Wet educatie en beroepsonderwijs inzake colleges van bestuur en raden van toezicht, Stb. 2009, 151: art. 9.1.8.

17. Art. 2:129a/239a, 2:132/242 lid 1 en 2:134/244 lid 1 BW. op gelijke wijze dat bij of krachtens de statuten kan worden bepaald dat één of meer bestuurders rechtsgeldig kunnen besluiten omtrent zaken die tot zijn, respectievelijk hun taak behoren. In de parlementaire stukken wordt deze regel aangeduid met 'vereenvoudigde' besluitvorming. ${ }^{18}$ Met deze regeling wordt volgens de minister van Justitie in een praktische behoefte voorzien. ${ }^{19}$ De regeling houdt in dat het mogelijk is dat één of meer bestuurders samen een besluit nemen dat heeft te gelden als een besluit van het gehele bestuur.

Uit de parlementaire geschiedenis bij de Wet bestuur en toezicht (WBT), die op 1 januari 2013 in werking is getreden, blijkt dat volgens de minister van Justitie een dergelijk gevolg alleen kan worden bewerkstelligd als dit blijkt uit de wet:

'De wet gaat uit van besluitvorming door het bestuur. Zonder nadere wettelijke regeling kunnen met een bepaalde taak belaste leden van het bestuur niet zelfstandig besluiten nemen die als bestuursbesluiten hebben te gelden. ${ }^{20}$

Voor toepassing van de regeling is vereist dat er een uitwerking in de statuten en/of een statutaire basis bestaan. Belangrijk is dat het bestuur collectief verantwoordelijk blijft voor deze besluiten. De bestuurder die een besluit heeft genomen dat kan worden aangemerkt als een bestuursbesluit, dient de andere bestuurders dan ook tijdig en in voldoende mate van informatie hierover te voorzien. ${ }^{21}$ Deze verplichting zou echter, aldus de minister, niet in een apart artikel moeten worden opgenomen, omdat die plicht al bestaat op grond van artikel 2:8 BW. ${ }^{22}$ Tevens zou in de statuten nader kunnen worden uitgewerkt op welke wijze de informatieverstrekking dient te geschieden. ${ }^{23}$ De andere bestuurders hebben een 'haalplicht'. ${ }^{24}$ Indien een bestuurder zijn tak niet of onjuist uitvoert, kunnen de andere bestuurders deze taak naar zich toe trekken. ${ }^{25}$ In de literatuur is betoogd dat de collectieve verantwoordelijkheid ertoe leidt dat de andere bestuurders ook instructies kunnen geven ter zake van de wijze en de inhoud van het besluit. ${ }^{26}$ Daarnaast zou de vereenvoudigde besluitvorming niet gelden bij besluiten angaande taken die niet kunnen worden verdeeld of een verstrekkende impact hebben, zoals het algemeen (financiële) beleid en het bepalen van de strategie, alsook sub-

18. Kamerstukken I 2010/11,31763, C, p. 24.

19. Kamerstukken II 2008/09, 31763, 6, p. 13.

20. Kamerstukken II 2008/09, 31763, 3, p. 17.

21. Zie o.a. Kamerstukken II 2008/09, 31763, 6, p. 25.

22. Kamerstukken II 2008/09, 31763, 6, p. 13 en 25.

23. Kamerstukken II 2008/09, 31763, 3, p. 17. Zie ook W. Bosse \& A.J. Raat, De taakbelaste bestuurder met besluitbevoegdheid. Gevolgen voor de collectieve bestuursaansprakelijkheid?, TOP 2015, afl. 4, p. 40-43.

24. Kamerstukken II $2008 / 09,31763,6$, p. 13

25. Kamerstukken I 2010/11,31763, C, p. 15.

26. A.F. Verdam, Van collegiaal bestuur, bestuursbesluiten, aantastbaarheid en delegatie en het besluit van een bestuurslid onder het nieuwe artikel 2:129a lid 3, Ondernemingsrecht 2013/102, p. 503-510. 


\section{Maandblad}

Ondernemingsrecht

stantiële transacties en samenwerkingsverbanden die een aanzienlijke invloed hebben op de rechtspersoon. ${ }^{27}$

Bij een one-tier board kan de taakverdeling te maken hebben met het onderscheid in taken tussen uitvoerende en niet-uitvoerende bestuurders, maar ook binnen deze groepen kan een taakverdeling bestaan. De eerste verdeling is van belang in het kader van bepaalde taken die niet (exclusief) aan uitvoerende bestuurders kunnen worden toegekend, zoals toezicht houden, het vaststellen van de bezoldiging van uitvoerende bestuurders en het doen van voordrachten voor de benoeming van een bestuurder. De tweede verdeling heeft met name te maken met een efficiënte(re) uitvoering van de bestuurstaken door bestuurders die in het bijzonder gekwalificeerd zijn op het terrein van de aan hem/haar toebedeelde taak. Deze laatste verdeling komt ook voor in het dualistische model. Ook in dat bestuurssysteem is het mogelijk dat er een taakverdeling plaatsvindt. Voor dit systeem is echter geen gelijkluidende regeling als die van Ontwerp-artikel 2:9a lid 2 in Boek 2 BW opgenomen, ook niet in het WBTR. Over het verschil in beschikbaarheid van deze vorm van besluitvorming is in de parlementaire geschiedenis van de WBT het volgende te vinden:

'Artikel 2:129a lid $3 \mathrm{BW}$ is uitsluitend voor het monistische bestuursmodel geschreven naar aanleiding van een verzoek uit de praktijk; voor het dualistische bestuursmodel is dat verzoek niet gedaan. ${ }^{28}$

In het kader van het Ambtelijk voorontwerp monistisch bestuursmodel coöperatie en onderlinge waarborgmaatschappij (AVMBCOW) heeft de Gecombineerde Commissie Vennootschapsrecht de suggestie gedaan een gelijke regel voor het dualistische systeem in te voeren. De minister van Justitie merkte het volgende op over het feit dat de suggestie niet was opgevolgd:

'Dit wetsvoorstel heeft tot doel het wettelijke monistische stelsel dat nu geldt voor de NV en BV ook vast te leggen voor de coöperatie en onderlinge waarborgmaatschappij. Er wordt niet beoogd wijzigingen aan te brengen in het dualistische stelsel waarin een apart orgaan belast is met de toezichthoudende en adviserende taak. Daar komt bij dat de verhouding tussen bestuurders binnen het dualistische stelsel verschilt van de verhouding tussen uitvoerende en niet uitvoerende bestuurders binnen het monistische stelsel. In het monistische stelsel is immers altijd sprake van een taakverdeling tussen de uitvoerende en de niet uitvoerende bestuurders. In dat geval kan delegatie van besluitvorming nuttig zijn, bijvoorbeeld om te bewerkstelligen dat de uitvoerende bestuurders gezamenlijk een bestuursbesluit kunnen nemen over zaken die met de dagelijkse lei-

27. S.H.M.A. Dumoulin, Het monistische bestuursmodel volgens de Wet bestuur en toezicht - observaties vanuit de praktijk, Ondernemingsrecht 2012/90, p. 488-495.

28. Kamerstukken I 2010/11, 31763, C, p. 24. ding te maken hebben. In een dualistisch stelsel hebben alle bestuurders in beginsel dezelfde taak, het besturen van de vennootschap. ${ }^{29}$

Deze redenering sluit niet goed aan bij de praktijk waarin ook in een dualistisch stelsel taakverdeling plaatsvindt.

De vraag rijst of het voorgaande betekent dat het bij het dualistische bestuursmodel niet mogelijk is dat een bestuurder of een deel van het bestuur een besluit kan nemen dat geldt als een bestuursbesluit. In de literatuur is betoogd dat machtiging van één of meer bestuurders om op een bepaald terrein een besluit te nemen, ook een bestuursbesluit oplevert. ${ }^{30}$ Omdat het artikel 2:129a lid $3 \mathrm{BW}$ niet op het dualistische model van toepassing is, zou het WBTR niet verhinderen dat de bestaande praktijk gebruik kan blijven maken van een bestuursbesluit dat tot stand gekomen is via een mandaat aan één of meer bestuurders. ${ }^{31}$ Dit is eigenlijk een vreemde situatie omdat er niet een duidelijke rechtvaardiging bestaat voor het maken van onderscheid tussen het one-tier en het two-tier bestuursmodel in dit opzicht. De wettelijke regel voor de besluitvorming bij de one-tier board heeft immers niet alleen betrekking op de te onderscheiden taken van uitvoerende bestuurders aan de ene kant en niet-uitvoerende bestuurders aan de andere kant. Bovendien is Ontwerp-artikel 2:9a lid $2 \mathrm{BW}$ niet nodig om ervoor te zorgen dat niet-uitvoerende bestuurders bepaalde besluiten kunnen nemen zonder dat daarbij de uitvoerende bestuurders betrokken zijn. Dit volgt al uit Ontwerp-artikel 2:9a lid 1 jo. lid 5 BW, waarbij het niet deelnemen aan de besluitvorming begrepen moet worden als de besluitvorming bij tegenstrijdig belang. ${ }^{32}$ In het WBTR of de toelichting daarop is geen aandacht geschonken aan deze discrepantie. Het gevolg is dat bij een one-tier board de besluitvorming niet wordt vereenvoudigd maar eigenlijk wordt bemoeilijkt, aangezien een statutaire bepaling nodig is om één of meer bestuurders te mandateren. De in de statuten opgenomen bevoegdheid wordt echter beperkt doordat bestuurders instructies kunnen geven over het te nemen besluit of zelfs de taak aan zich kunnen trekken bij onjuiste uitvoering, zoals blijkt uit de parlementaire geschiedenis. ${ }^{33}$ Hierdoor is de regeling in de literatuur aangemerkt als verwarrend, omdat de statuten gewoonlijk de regels stellen waaraan ook het bestuur is onderworpen. ${ }^{34}$

Door de bredere toepassing van het monistische model wordt de groep rechtspersonen die zich geconfronteerd ziet met Ontwerp-artikel 2:9a lid 2 BW uitgebreid. Hoewel dit artikel eigenlijk een regel betreft uit de WBT en dus niet nieuw is,

29. MvT bij het AVMBCOW, p. 3: <www.internetconsultatie.nl/ monistisch_bestuursmodel_cooperatie_onderlinge_waarborgmaatschap pij>.

30. Verdam 2013

31. M. van Olffen, Inrichting van de one tier vennootschap bij of krachtens de statuten, Ondernemingsrecht 2012/89, p. 481-487.

32. Van Olffen 2012.

33. Kamerstukken I 2010/11, 31763, C, p. 15

34. Verdam 2013 


\section{Maandblad \\ Ondernemingsrecht}

zou indien wordt vastgehouden aan de in de MvT vermelde doelstelling van het WBTR, namelijk aanvulling en verduidelijking van de regeling voor bestuur en toezicht (in tegenstelling tot de in onze ogen oorspronkelijke doelstelling: zie par. 3), toch ingegaan moeten worden op het verschil van de toepasselijkheid van een dergelijke regel bij de one-tier en de two-tier board en de rechtvaardiging van dat onderscheid. Bovendien zou in het kader daarvan de voorgaande conclusie dat de regel van Ontwerp-artikel 2:9a lid 2 BW de besluitvorming bij de one-tier board eigenlijk complexer makt, aan bod moeten komen. Het lijkt daarbij echter zinvol om in lijn met het advies van de Raad van State de evaluatie van de WBT af te wachten voordat inhoudelijk verder wordt gegaan met het WBTR. ${ }^{35}$ Het is dan wel zaak dat deze regel onderdeel uitmaakt van die evaluatie.

\section{Conclusie}

Het onderhavige wetsvoorstel is op zichzelf een lovenswaardige poging om het bestuur en toezicht bij alle rechtspersonen meer te stroomlijnen en beter op elkaar af te stemmen. Het lokt interessante debatten onder vennootschapsjuristen uit van vooral juridisch-technische aard. Ook ons commentaar vormt een bijdrage daaraan. Uit onze analyse blijkt dat het wetsvoorstel op onderdelen nog niet echt voldragen is en verdere doordenking behoeft. Zo geeft Ontwerp-artikel 2:11 lid 6 $\mathrm{BW}$ nog niet veel duidelijkheid voor de situatie dat een $\mathrm{RvC}$ ontbreekt. Bij de keuze in de Ontwerp-artikelen 2:9c en 2:11c BW voor onbezoldigdheid als beslissend criterium om de bewijsvermoedens van - thans - artikel 2:138/248 BW buiten toepassing te laten bij faillissementsaansprakelijkheid van bestuurders en commissarissen kan men vraagtekens plaatsen. Tevens is onduidelijk wat een onderscheid in de regeling aangaande besluitvorming door de taakbelaste bestuurder(s) bij het monistische en dualistische systeem rechtvaardigt. Bij de keuze voor een regel die vervolgens in beide systemen wordt toegepast, zou het uitgangspunt moeten zijn dat er daadwerkelijk een vereenvoudiging in de besluitvorming plaatsvindt in plaats van deze complexer te maken, zoals de wetgever bij het monistische stelsel heeft bewerkstelligd door een statutaire bepaling te vereisen die toestaat dat bestuurders met een bepaalde taak zelfstandig besluiten kunnen nemen die als bestuursbesluiten hebben te gelden, zonder welke een dergelijke besluitvorming niet kan plaatsvinden.

Wat ons vooral stoort is het feit dat het wetsvoorstel nauwelijks een adequate respons bevat op de in het recente verleden voorgekomen deconfitures in de semipublieke sector. Zo wordt zelfs niet de vraag geopperd of invoering van een verplicht toezichthoudend orgaan onder omstandigheden effectief kan zijn om dergelijke affaires in de toekomst te voorkomen. Ook van de dechargeproblematiek wordt niet gerept. Blijft dit zo, dan dreigt het wetsvoorstel uit te monden in een gemiste kans van de wetgever.
De door ons bepleite verbeteringen in het wetsvoorstel zouden bij nota van wijziging kunnen worden overgenomen door de regering. Maar de parlementaire geschiedenis van de WBT uit 2008 en 2009 heeft laten zien dat ook de Tweede Kamer zich bewust is van haar wetgevende taak: waar nodig zou ook het WBTR bij amendement kunnen worden aangepast.

35. Kamerstukken II 2015/16, 34491, 4, p. 8. 